\title{
Epidemiology and Risk Factors of Post Operative Site Infections in Surgical Patients: A Systematic Review
}

\author{
Mohammad Salahuddin', Farahnaz Muddebihal ${ }^{2}$, Ashokkumar Thirunavukkarasu ${ }^{3}$, Abdulhadi Abdullah Z Alanazi ${ }^{4}$, Ahmed Mutiq \\ Subayyil Alrash $\mathrm{di}^{4}$, Adel Mamdouh Alrashidi ${ }^{4}$, Wael Owaid H Alanazi ${ }^{4}$, Abdulelah Hamdan R Alruwaili ${ }^{4}$, Abdulrahman Fayez J \\ Alruwaili ${ }^{4}$, Khalid Nuwaysir Alruwaili ${ }^{4}$
}

${ }^{1}$ Department of Physiology, College of Medicine, Jouf University, Sakaka, Saudi Arabia. ${ }^{2}$ Department of Preventive Dentistry, Oral Pathology \& Microbiology, College of Dentistry, Jouf University, Sakaka, Saudi Arabia. ${ }^{3}$ Department of Community Medicine, College of Medicine, Jouf University, Sakaka, Saudi Arabia. ${ }^{4}$ College of Medicine, Jouf University, Sakaka, Saudi Arabia.

\section{Abstract}

Surgical site infection (SSI) is one of the most common and serious hospital-acquired infections all over the world. The SSI can lead to an increase in morbidity, mortality, and increase in the duration of hospital stay among patients. The present systematic review was planned to find the epidemiological features, prevalence, causative organisms, and predisposing risk factors for the development of postoperative infections among surgical patients of all the six WHO regions. Initially, 281 articles were identified through specified databases. Finally, 18 articles that fulfilled all inclusions and exclusion criteria are included. For the risk factors assessment, p-values, odds ratio were considered. In general, the occurrence rate of SSI ranges from $2 \%$ to $17.8 \%$. Regarding causative organisms, three microorganisms are commonly reported in most of the studies were Staphylococcus aureus, Klebsiella pneumonia, and E.Coli. Among the different procedures reviewed, incidence and prevalence rates were higher among emergency surgical procedures and lower among obstetrics and gynecology procedures. Longer preoperative duration of stays in hospital decreased $\mathrm{Hb}$ and serum albumin level, comorbid conditions such as diabetes, hypertension are potential risk factors for the development of SSI. The occurrence rate of SSI among post-operative patients is very high, especially in developing countries. This leads to a double burden on the healthcare delivery settings during the COVID-19 pandemic. It is essential to include a strict infection control policy, fair usage of antibiotics practices to be implemented. It is also recommended to control comorbid conditions before planning for elective surgery.

Keywords: Surgical site infection, Risk Factors, Prevalence, Causative organisms

\section{INTRODUCTION}

Surgical site infection (SSI) is one of the most common and serious hospital-acquired infections all over the world [1-3]. According to the Centre for Disease Control and Prevention (CDC), surgical site infection is defined as "post-operative infections that develop in 30 days after any surgical procedure or within one year of any implants [4]. All over the world, around 300 million surgeries are performed every year. This increasing number of surgeries leads to an increase in the incidence of postoperative wound infections on surgical sites [5]. A recent report published by the World Health Organization (WHO) that surgical site infection (SSI) is one of the commonly occurring hospital-acquired infections (HAI) in low- and middle-income countries. This affects up to one-third of patients who have undergone a surgical procedure. Although SSI frequency is lower in developed countries, it remains the second most common type of HAI in the USA [6].

In the Kingdom of Saudi Arabia, several studies found the incidence of surgical site infections ranges from $6.8 \%$ to $24 \%$ [7-9]. Several studies have been done to assess the SSI of the particular site such as the ankle, breast, and more $[10,11]$.
The infection in a surgical wound is an indication of the disrupted host-microorganism equilibrium that leads to colonization of the bacteria on the surgical site. As a result, the wound healing process is greatly affected, and systemic response also will manifest [12].

The consequences and impact of postoperative wound infections have been published exhaustively all over the world that included an increase in morbidity, mortality, and

Address for correspondence: Dr. Mohammad Salahuddin MD, Associate Professor of Physiology, College of Medicine, Jouf University, Saudi Arabia. Email: mskhaja @ ju.du.sa

This is an open-access article distributed under the terms of the Creative Commons Attribution-Non Commercial-Share Alike 3.0 License, which allows others to remix, tweak, and build upon the work non commercially, as long as the author is credited and the new creations are licensed under the identical terms.

How to cite this article: Salahuddin $M$, Muddebihal $F$, Thirunavukkarasu A, Alanazi A A Z, Alrashdi A M S, Alrashidi A M, et al. Epidemiology and Risk Factors of Post Operative Site Infections in Surgical Patients: A Systematic Review. Arch. Pharm. Pract. 2022;13(1):31-6. https://doi.org/10.51847/ZOIxqqgVc6 
increase in the duration of hospital stay. This SSI also leads to readmission of the patients, failure of primary surgical methods, and so on. This increasing incidence of SSI also impacts an additional burden on health care expenditure and the need for additional resources [13-15]. This leads to a further increase in the pressure on health care systems which is already overburdened due to the coronavirus - 19 (COVID19) pandemics, especially in developing countries $[16,17]$. Hence, it has become more important to understand the epidemiology, causative organisms, and risk factors for the SSI for the prevention of SSI.

In most post-operative infection cases, the causative organisms are endogenous in origin; the commonly found in SSI clinical isolates are Staphylococcus aureus, enterococci, E.Coli and coagulase-negative staphylococcus. Some studies have found that methicillin-resistant staphylococcus (MRSA) was also responsible for SSI $[18,19]$. This scenario further makes things complicated as MRSA organisms are difficult to treat. In the past, some of the authors have made attempts to find the different risk factors for postoperative infections and commonly reported factors are the long duration of surgery, improper pre-operative preparation of the skin, type of surgery, impaired physiological states such as hypoxia, hypothermia, shock and associated co-morbid conditions (diabetes mellitus, obesity, and immune deficiency) [20-22]. Some of the authors in the past have attempted to do systematic reviews on the SSI; but with our extensive review of literature, there are limited systematic reviews available that cover the epidemiological characteristics and risk factors $[23,24]$. Hence, this systematic review was planned to find the epidemiological features, prevalence, causative organisms, and predisposing risk factors for the development of postoperative infections among surgical patients of all the six WHO regions.

\section{Materials and Methods}

The present systematic review was made as per the Preferred Reporting Items for Systematic Reviews (PRISMA) reporting statements and guidelines.

\section{Search methods and inclusion criteria}

The research team made extensive literature searches from PubMed/Medline, Cochrane Library, Embase, and Database of Abstracts of Reviews of Effects (DARE). The search methods involved the keyword "post-operative infection," "surgical site infection," "prevalence of surgical site infection," "incidence of surgical site infection," "risk factor," and "causative organism". Firstly, articles published in the English language are only included and other language articles are excluded. The article was published during the last ten years; all the surgical specialties (including dental science) were included in the present review. Also, those articles must have been published in a peer-reviewed journal with an International Standard Serial Number (ISSN).
All the authors have collected the articles as per the inclusion criteria. After the collection and compilation of articles, two independent authors (first and second) reviewed and included articles for data extraction and synthesis. The extracted data is initially screened based on title and abstract and then eligible articles were further assessed for data extraction. The extracted data include types of study design, sample size, prevalence, potential risk factors, and causative microorganisms. The potential risk factors evidence was synthesized based on p-value and/or odds ratio (OR), while other data were synthesized based on frequency and proportion.

\section{Results and Discussion}

The below figure (PRISMA flow chart) summarizes the data extraction process for this systematic review. The number of articles included and excluded in the different stages based on the data extraction criteria is described. These articles are published in peer-reviewed journals during the past 10 years. Initially, there were around 282 articles were identified in this review. Subsequently, after exclusion from each stage, a total of 18 full-text articles were assessed for evidence synthesis.



Figure 1. PRISMA Flow Chart

Table 1 describes the general characteristics included in this review in terms of WHO regions, types of study designs, and types of surgery. The present study included 4 (22.2\%) articles from the Southeast region and $61.1 \%$ included articles were based on elective surgical procedures.

$\begin{aligned} & \text { Table 1. General characteristics of the included study } \\ & (n=18)\end{aligned}$
Characteristics
WHO Regions




\begin{tabular}{ccc} 
The African Region & 3 & 16.7 \\
The Region of the Americas & 3 & 16.7 \\
The Eastern Mediterranean Region & 3 & 16.7 \\
The European Region & 2 & 11.1 \\
The South-East Asia Region & 4 & 22.2 \\
The Western Pacific Region & 3 & 16.7 \\
Type of study design & & \\
Cross-sectional & 6 & 33.3 \\
Retrospective & 7 & 38.8 \\
Prospective/Cohort & 5 & 27.7 \\
$\quad$ Types of surgery & & \\
Elective & 11 & 61.1 \\
Emergency & 7 & 38.9 \\
\hline
\end{tabular}

Study description, major outcomes including the prevalence of SSI in different regions of the world are presented below table. A minimum of one article is selected from each of the six WHO regions. In general, the occurrence rate of SSI ranges from $2 \%$ to $17.8 \%$. Regarding causative organisms, three microorganisms are commonly reported in most of the studies were Staphylococcus aureus, Klebsiella pneumonia, and E.Coli. Among the different procedures reviewed, incidence and prevalence rates were higher among emergency surgical procedures and lower among obstetrics and gynecology procedures (Table 2).

\begin{tabular}{|c|c|c|c|}
\hline Author, Year & Country/Region & Study description & Key findings \\
\hline $\begin{array}{l}\text { Lubega A et al, } 2017 \\
\qquad[25]\end{array}$ & Uganda, the African region & $\begin{array}{c}\text { Prospective study } \\
\mathrm{N}=114, \text { Emergency post-operative patients }\end{array}$ & $\begin{array}{c}\text { Incidence }-16.4 \% \\
\text { Klebsiella Pneumonia is the most common } \\
\text { organism (50\%) followed by S.Aureus }(27.8 \%)\end{array}$ \\
\hline $\begin{array}{c}\text { Torres S et al, } 2018 \\
{[26]}\end{array}$ & Brazil, Region of Americas & $\begin{array}{l}\text { Retrospective study } \\
\quad \mathrm{N}=178 \\
\text { Craniotomy patients }\end{array}$ & Incidence $-11.6 \%$ \\
\hline $\begin{array}{c}\text { Kumar A et al, } 2017 \\
\text { [27] }\end{array}$ & $\begin{array}{l}\text { India, South-East Asian } \\
\text { Region }\end{array}$ & $\begin{array}{c}\text { Retrospective } \\
\mathrm{N}=3321 \text { elective and } 451 \text { emergencies } \\
\text { All general surgical unit patients }\end{array}$ & $\begin{array}{c}\text { Prevalence }-17.7 \% \text { in emergency surgeries and } \\
12.5 \% \text { elective surgeries }\end{array}$ \\
\hline
\end{tabular}

\begin{abstract}
$\begin{array}{cc}\text { Alshammari et al, } & \text { Saudi Arabia, Eastern } \\ 2020[28] & \text { Mediterranean Region }\end{array}$
\end{abstract} Dessie W et al, 2016 Ethiopia, African Region
[29]
Morikane K et al, Japan, Western Pacific 2016 [30] region
Negi V, 2018 [31] India, South-East Asian Region $\begin{array}{cc}\text { Pathak A et al, } 2017 & \text { India, South-East Asian } \\ \text { [32] } & \text { Region }\end{array}$ Rouse T et al, 2019 Canada, American region
[33] $\begin{array}{cc}\text { Li Z et al, } 2021 \text { [34] } & \text { China, Western Pacific } \\ \text { region }\end{array}$
Brennfleck FW et al, German, European 2020 [35] summarizes the region
A 10-year retrospective study from a tertiary care hospital

A cross-sectional study was done on 107 SSI patients to find the causative organisms

A retrospective study from the nationwide database Gastric surgery patients

$$
\begin{gathered}
\text { Cross-sectional study } \\
\mathrm{N}=768
\end{gathered}
$$

$$
\text { Cross-sectional study }
$$$$
\mathrm{N}=1173
$$

Obstetrics and Gynecology

Prospective study

$\mathrm{N}=120$

OBG-GYN patients
Prospective multicentric study

$$
\mathrm{N}=953
$$
Emergency abdominal surgery

Retrospective
The prevalence rate ranges from 20 per 1000 in 2009 to 3.5 per 1000 in 2018

E.Coli was the commonest infective microorganisms (23.1\%). Multi-drug resistance was highly prevalent.

\section{Rate of SSI $8.8 \%$}

Prevalence $-17.8 \%$

The order of common organisms:

S. aureus $-50.4 \%$

E.coli $-23.02 \%$,

P. aeruginosa $-7.9 \%$

The rate of occurrence of SSI was $7.84 \%$

Incidence rate $-5.9 \%$

The incidence rate is $7.5 \%$

The commonest pathogen was E.coli $-29.6 \%$ positivity rate.

Superficial SSI - $13.5 \%$

Deep incisional $-9 \%$

Organ space $-2.4 \%$
Table 3 potential risk factors for the development of SSI in the different study populations. The study included finding that associated risk factors were reviewed based on their pvalue and/or odds ratio (OR) with the $95 \%$ confidence interval (CI). The OR value of more than one and 95\% CI value does not include a null value of one is considered as a positive association. The higher the confidence interval indicates the strength of association is higher. In general, longer preoperative duration stay in the hospital, decreased $\mathrm{Hb}$ and serum albumin level, comorbid conditions such as 
diabetes, hypertension are potential risk factors for the development of SSI.

\begin{tabular}{|c|c|c|c|}
\hline $\begin{array}{l}\text { Author, } \\
\text { Year }\end{array}$ & $\begin{array}{l}\text { Country/ } \\
\text { Region }\end{array}$ & Study description & Risk factors \\
\hline $\begin{array}{l}\text { Lubega A et } \\
\text { al, } 2017[25]\end{array}$ & $\begin{array}{l}\text { Uganda, the African } \\
\text { region }\end{array}$ & $\begin{array}{l}\text { Prospective study } \\
\mathrm{N}=114, \text { Emergency post- } \\
\text { operative patients }\end{array}$ & $\begin{array}{l}\text { Wound class }(p=0.009), \downarrow \text { serum albumin }(p=0.046) \text {, Type of suture } \\
\text { material }(p=0.006), \downarrow \text { Hb level }(p=0.024),\end{array}$ \\
\hline $\begin{array}{l}\text { Alghamdi et } \\
\text { al, } 2021[36]\end{array}$ & $\begin{array}{l}\text { Saudi Arabia, Eastern } \\
\text { Mediterranean } \\
\text { Region }\end{array}$ & $\begin{array}{l}\text { Retrospective case-control study } \\
\qquad \mathrm{N}=221 \\
\text { Spinal surgery patients }\end{array}$ & $\begin{array}{c}\text { Longer post-operative duration stays at hospital- } \mathrm{p}=.004, \mathrm{OR}(95 \% \mathrm{CI}) \\
\qquad \begin{aligned} \\
\end{aligned} \\
\text { Hypertension }-\mathrm{p}=.02, \mathrm{OR}(95 \% \mathrm{CI})=5.62(1.19-24.47) \\
\text { Higher ASA score } \mathrm{p}=0.04, \text { OR }(95 \% \mathrm{CI})=26.0(1.16-583.46) \\
\text { Blood transfusion - } \mathrm{p}<0.01, \text { OR }(95 \% \mathrm{CI})=23.3(4.43-122.73)\end{array}$ \\
\hline $\begin{array}{l}\text { Mekhala et } \\
\text { al, } 2019[37]\end{array}$ & $\begin{array}{l}\text { India, South-East } \\
\text { Asian Region }\end{array}$ & $\begin{array}{l}\text { Prospective cohort study } \\
\quad \mathrm{N}=100 \\
\text { Intra-abdominal surgery patients }\end{array}$ & $\begin{array}{c}\text { Diabetes, Preoperative anemia, } \downarrow \text { serum albumin, long duration of } \\
\text { surgery. }\end{array}$ \\
\hline $\begin{array}{l}\text { Torres S et } \\
\mathrm{al}, 2018[26]\end{array}$ & $\begin{array}{l}\text { Brazil, Region of } \\
\text { Americas }\end{array}$ & $\begin{array}{l}\text { Retrospective study } \\
\quad \mathrm{N}=178 \\
\text { Craniotomy patients }\end{array}$ & $\begin{array}{l}\text { Surgery duration }>4 \text { hours }(\mathrm{OR}=1.49 ; 95 \% \mathrm{CI}, 0.96-2.30 ; \mathrm{p}=0.046) \\
\text { More drain time }(\mathrm{OR}=4.67 ; 95 \% \mathrm{CI}, 1.34-16.00 ; \mathrm{p}=0.015) \\
\text { Patient with reoperation }(\mathrm{OR}=4.38 ; 95 \% \mathrm{CI}, 1.14-16.74 ; \mathrm{p}=0.03)\end{array}$ \\
\hline $\begin{array}{l}\text { Azeze et al, } \\
2019[38]\end{array}$ & $\begin{array}{l}\text { Ethiopia, African } \\
\text { Region }\end{array}$ & $\begin{array}{l}\text { Cross-sectional study } \\
\quad \mathrm{N}=383 \\
\text { Post cesarian section }\end{array}$ & $\begin{array}{c}\text { Rupture of membrane }(\mathrm{aOR}(95 \% \mathrm{CI})=13.9(2.99-64.8), \\
\text { Surgery duration }>30 \text { mins }(\mathrm{aOR}(95 \% \mathrm{CI})=4.9,(1.8-13.1), \\
\text { Improper skin closure methods }(\mathrm{aOR}(95 \% \mathrm{CI})=6.29(2.07-19.11)\end{array}$ \\
\hline $\begin{array}{l}\text { Patel S et al, } \\
2019[39]\end{array}$ & $\begin{array}{l}\text { The United } \\
\text { Kingdom, European } \\
\text { region }\end{array}$ & $\begin{array}{l}\text { Retrospective study } \\
\qquad \mathrm{N}=16513\end{array}$ & $\begin{array}{c}\text { Longer duration of surgery; } \mathrm{p}=0.018, \mathrm{OR}(95 \% \mathrm{CI})=2.36(1.16-4.79) \\
\text { Use of dexamethasone; } \mathrm{p}<0.01, \mathrm{OR}(95 \% \mathrm{CI})=3.03(1.71-5.36) \\
\text { Wound; } \mathrm{p}<0.01, \mathrm{OR}(95 \% \mathrm{CI})=27.77(16.36-47.15)\end{array}$ \\
\hline $\begin{array}{l}\text { Carvalho et } \\
\text { al, } 2017[40]\end{array}$ & $\begin{array}{l}\text { Brazil, Region of } \\
\text { Americas }\end{array}$ & $\begin{array}{l}\text { Non-concurrent cohort study } \\
\qquad \mathrm{N}=16882\end{array}$ & $\begin{array}{c}\text { More preoperative stay at the hospital ( }>24 \text { hours), contaminated } \\
\text { wounds, ASA class III and IV }\end{array}$ \\
\hline $\begin{array}{l}\text { Zhang X et } \\
\text { al, } 2020[41]\end{array}$ & $\begin{array}{l}\text { China, Western } \\
\text { pacific region }\end{array}$ & $\begin{array}{l}\text { Cross-sectional study } \\
\quad \mathrm{N}=1046 \\
\text { Colorectal surgery patients }\end{array}$ & $\begin{array}{l}\text { Hypertension; } \mathrm{P}=0.025, \mathrm{OR}-1.90(95 \% \mathrm{CI}=1.09-3.32), \text { nosocomial } \\
\text { infection surveillance risk index score of } 2 \text { or } 3 ; \mathrm{p}<0.01, \mathrm{OR}=3.84 \\
(95 \% \mathrm{CI}=1.93-7.66)\end{array}$ \\
\hline $\begin{array}{l}\text { Mirzashahi et } \\
\text { al, } 2019[42]\end{array}$ & $\begin{array}{c}\text { Iran, Eastern } \\
\text { Mediterranean region }\end{array}$ & $\begin{array}{l}\text { Cross-sectional study } \\
\quad \mathrm{N}=78 \\
\text { Aged } 18 \text { years and above }\end{array}$ & $\begin{array}{l}\text { Dental caries }(P=0.016) \text {, history of dental abscess }(\mathrm{p}=0.023) \text {, and the } \\
\text { presence of periodontal disease }(\mathrm{P}=0.049)\end{array}$ \\
\hline
\end{tabular}

The postoperative infection/SSI is one of the growing challenges for the health care delivery sectors. Prevention and control of SSI are some of the essential components for the reduction of health care delivery costs and this is now more essential as COVID-19 pandemics crippling the health care delivery, especially in developing countries. The present systematic review was aimed to identify the epidemiological characteristics and risk factors for the development of SSI in all six WHO regions.

The present review revealed that the occurrence of SSI ranges from $2 \%$ to $17.8 \%$. These huge variations in the occurrence are influenced by several factors. Firstly, the Southeast region countries reporting a higher incidence of SSI, while Eastern Mediterranean countries reported a lower incidence of SSI. Similar to our review, a study done by Lateefa A et al in the kingdom of Saudi Arabia in 2020 revealed that the frequency of SSI occurrence is very low during the past five years [28]. In contrast to our finding, a study was done by Khan UF in
Pakistan (a part of the South-east Asian WHO region) have reported a slightly higher proportion of SSI (29.8\%) among the patients who undergone seven different surgical procedures [43]. This emphasizes the importance of proper implementation of SSI preventive measures in these countries so that the additional burdens faced by the COVID-19 pandemic can be reduced.

Our study revealed that postoperative wound infections are commonly caused by S. Aureus (25to 55\%), E. Coli (26 to $53 \%$ ), and K. Pneumonia (12 to 25\%). Other reported organisms are P. Aurigonsa and gram-negative bacteria. Interestingly, a study done by Lubega A et al in Uganda has reported a very high proportion $(50 \%)$ of $\mathrm{K}$. Pneumonia as a causative organism among 114 emergency postoperative patients [25].

This systematic review investigated different potential risk factors for the development of SSI among post-operative 
patients. Consistently, co-morbidities were one of the major risk factors for the development of SSI. Several authors from different regions have reported the presence of comorbidities such as diabetes, hypertension, anemia, hypoalbuminemia, and renal impairments increase the risks of SSI [25, 36, 37]. Perioperative surgery duration is one of the important predictors of SSI development and longer the duration of surgery leads to higher risk, evidenced by the OR of 4.7 to 11 [26]. Similarly, the incidence of emergency surgical procedures has higher risks than elective surgical procedures $[28,33]$. This could be due to better control of comorbidities in a planned elective pre-operative surgery than the emergencies. Some surgery categories such as obstetrics and gynecology, orthopedics are reported to have a lower incidence of SSI [36]. The role of pre-operative dexamethasone is poorly evaluated, and data is limited. Dexamethasone is an inexpensive drug used for the prevention of postoperative vomiting. However, a study done by Patel et al in 2019 revealed that the use of dexamethasone increases the risk of SSI $(\mathrm{p}<0.01$, OR $(95 \% \mathrm{CI})=3.03(1.71-$ 5.36)).

Despite the best effort from our research team for this systematic review, certain limitations need to be considered while interpreting this systematic review. Firstly, the present study included only English-language articles. Hence, findings of non-English articles are not considered for review, this systematic review may not be applicable for global targets. The sample size of the majority of articles in this review is small. Finally, about one-third of included studies are case-control studies. Hence, the possibility of confounding bias needs to be considered while interpreting this systematic review.

\section{ConcLusion}

The occurrence rate of SSI among post-operative patients is very high, especially in developing countries. This leads to a double burden on the healthcare delivery settings during the COVID-19 pandemic. Common microorganisms responsible for SSI developments are S. Aureus, E. Coli, and K. Pneumonia. Numerous potential risk factors such as the presence of comorbidities, longer perioperative duration are identified. Hence, it is essential to include a strict infection control policy, fair usage of antibiotics practices to be implemented. It is also recommended to control comorbid conditions before planning for elective surgery.

\section{ACKNOWLEDGMENTS: None CONFLICT OF INTEREST: None FINANCIAL SUPPORT: None ETHICS STATEMENT: None}

\section{References}

1. Lewis SS, Moehring RW, Chen LF, Sexton DJ, Anderson DJ. Assessing the relative burden of hospital-acquired infections in a network of community hospitals. Infect Control Hosp Epidemiol. 2013;34(11):1229-30.
2. Sheikhi MA, Rahmani H. Inflammatory statuses of non-smoker mustard lung patient candidate for coronary artery bypass grafting surgery. Int J Pharm Res Allied Sci. 2016;5(3):194-5.

3. Hite GJ, Mishvelov AE, Melchenko EA, Vlasov AA, Anfinogenova OI, Nuzhnaya CV, et al. Holodoctor Planning Software Real-Time Surgical Intervention. Pharmacophore. 2019;10(2):1-2.

4. Berríos-Torres SI, Umscheid CA, Bratzler DW, Leas B, Stone EC, Kelz RR, et al. Surgical Perspective: Centers for Disease Control and Prevention Guideline for the Prevention of Surgical Site Infection 2017. JAMA Surg. 2017;152(8):784-91. doi: 10.1001/jamasurg.2017.0904

5. Weiser TG, Haynes AB, Molina G, Lipsitz SR, Esquivel MM, UribeLeitz T, et al. Size and distribution of the global volume of surgery in 2012. Bull WHO. 2018; 94(3):201-9.

6. Global guidelines on the prevention of surgical site infection [Internet]. 2016 [cited 2021 Jan 11]. Available from: https://www.who.int/gpsc/ssi-prevention-guidelines/en/

7. Khairy GA, Kambal AM, Al-Dohayan AA, Al-Shehri MY, Zubaidi AM, Al-Naami MY, et al. Surgical Site Infection in a Teaching Hospital: A Prospective Study. J Taibah Univ Med Sci. 2017;6(2):11420.

8. Al-Mulhim FA, Baragbah MA, Sadat-Ali M, Alomran AS, Azam MQ. Prevalence of surgical site infection in orthopedic surgery: a 5-year analysis. Int Surg. 2019;99(3):264-8. doi: 10.9738/INTSURG-D-1300251.1 .

9. Amer M, Alnawar YMH, Sendi FJE. Appraisal of Awareness of Surgical Staff about Surgical Site infection at Selected Surgical Units, Saudi Arabia. Int J Sci Res (IJSR). 2017;6(1):2362-5.

10. Al-Kenani NS, Alsultan AS, Alosfoor MA, Bahkali MI, Al-Mohrej OA. Incidence and predictors of surgical site infections following foot and ankle surgery. J Musculoskelet Surg Res. 2017;1:6-9.

11. Almuneef M, Memish Z, Balkhy H, Hijazi O, Cunningham G, Francis C. Rate, risk factors and outcomes of catheter-related bloodstream infection in a paediatric intensive care unit in Saudi Arabia. J Hosp Infect. 2016;62(2):207-13

12. Robson MC. Wound infection. A failure of wound healing caused by an imbalance of bacteria. Surg Clin North Am. 2007;77(3):637-50.

13. Olsen M, Tian F, Wallace A, Nickel K, Warren D, Fraser V, et al. Impact of Surgical Site Infections following common Ambulatory Procedures on Healthcare Costs. Value Health. 2015;18(3):A234.

14. Badia JM, Casey AL, Petrosillo N, Hudson PM, Mitchell SA, Crosby C. Impact of surgical site infection on healthcare costs and patient outcomes: a systematic review in six European countries. J Hosp Infect. 2017;96(1):1-15.

15. Cheadle WG. Surgical Site Infection: Still a Common Problem. JAMA Surg. 2013;148(2):189.

16. Hamid H, Abid Z, Amir A, Rehman TU, Akram W, Mehboob T. Current Burden on Healthcare Systems in low- and middle-income countries: Recommendations for Emergency Care of COVID-19. Drugs Ther Perspect. 2020;36(10):466-8.

17. Miller IF, Becker AD, Grenfell BT, Metcalf CJE. Disease and Healthcare Burden of COVID-19 in the United States. Nat Med [Internet]. 2020;26(8):1212-7. Available from: https://www.nature.com/articles/s41591-020-0952-y

18. Hassan RS, Osman SO, Aabdeen MA, Mohamed WE, Hassan RS, Mohamed SO. Incidence and root causes of surgical site infections after gastrointestinal surgery at a public teaching hospital in Sudan. Patient Saf Surg. 2020;14(1):1-7.

19. Bhattacharya S, Pal K, Jain S, Chatterjee SS, Konar J. Surgical site infection by methicillin resistant staphylococcus aureus-On decline?. J Clin Diagn Res: JCDR. 2016;10(9):DC32.

20. Korol E, Johnston K, Waser N, Sifakis F, Jafri HS, Lo M, et al. A Systematic Review of Risk Factors Associated with Surgical Site Infections among Surgical Patients. Khan A, editor. PLoS ONE [Internet]. 2013;8(12):e83743. Available from: https://www.ncbi.nlm.nih.gov/pmc/articles/PMC3867498/

21. Catania VD, Boscarelli A, Lauriti G, Morini F, Zani A. Risk Factors for Surgical Site Infection in Neonates: a Systematic Review of the Literature and Meta-Analysis. Front Pediatr [Internet]. 2019 Mar 29 [cited 2019 Jun 12];7. Available from: https://www.frontiersin.org/articles/10.3389/fped.2019.00101 
22. Hegy A, Alshaalan S, Alkuraya H, Aljabbab N, Alruwaili H, Alanazi N. Surgical Site infection: a Systematic Review. Int J Med Dev Ctries [Internet]. 2021 [cited 2021 Aug 3];730-7. Available from: https://ijmdc.com/fulltext/51-1605163946.pdf

23. Subramanyam R, Schaffzin J, Cudilo EM, Rao MB, Varughese AM. Systematic Review of Risk Factors for Surgical Site Infection in Pediatric Scoliosis Surgery. Spine J. 2015;15(6):1422-31.

24. Purba AKR, Setiawan D, Bathoorn E, Postma MJ, Dik J-WH, Friedrich AW. Prevention of Surgical Site Infections: a Systematic Review of Cost Analyses in the Use of Prophylactic Antibiotics. Front Pharmacol. 2018;9:776.

25. Lubega A, Joel B, Justina Lucy N. Incidence and Etiology of Surgical Site Infections among Emergency Postoperative Patients in Mbarara Regional Referral Hospital, South Western Uganda. Surg Res Pract. 2017;2017:1-6.

26. Torres S, Perdiz LB, Medeiros EA. Incidence of Surgical Site Infection after craniotomy: Comparison between Three Months and Twelve Months of Epidemiological Surveillance. Braz $\mathrm{J}$ Infect Dis. 2018;22(5):433-7.

27. Kumar A, Rai A. Prevalence of Surgical Site Infection in General Surgery in a Tertiary Care Centre in India. Int Surg J. 2017;4(9):3101.

28. Alshammari LT, Alkatheer SA, AlShoaibi MB, Alomran AA, Almulhim SN, Aljindan RY, et al. Surgical site infections in a tertiary hospital over 10 years. Saudi Med J. 2020;41(9):971-6.

29. Dessie W, Mulugeta G, Fentaw S, Mihret A, Hassen M, Abebe E. Pattern of Bacterial Pathogens and Their Susceptibility Isolated from Surgical Site Infections at Selected Referral Hospitals, Addis Ababa, Ethiopia. Int J Microbiol. 2016;2016:1-8.

30. Morikane K, Honda H, Suzuki S. Factors Associated with Surgical Site Infection following Gastric Surgery in Japan. Infect Control Hosp Epidemiol. 2016;37(10):1167-72.

31. Negi V. Bacteriological Profile of Surgical Site Infections and Their Antibiogram: a Study from Resource-Constrained Rural Setting of Uttarakhand State, India. J Clin Diagn Res [Internet]. 2015; Available from: https://www.ncbi.nlm.nih.gov/pmc/articles/PMC4625239/

32. Pathak A, Mahadik K, Swami MB, Roy PK, Sharma M, Mahadik VK, et al. Incidence and Risk Factors for Surgical Site Infections in Obstetric and Gynecological Surgeries from a Teaching Hospital in Rural India. Antimicrob Resist Infect Control. 2017;6(1):1-8.
33. Rouse T, Nascu P, Dawson C, Morris E. Incidence of Surgical Site Infections after Caesarean Sections in a Community Hospital. Can J Infect Control. 2019;34(1):30-4.

34. Li Z, Li H, Lv P, Peng X, Wu C, Ren J, et al. Prospective Multicenter Study on the Incidence of Surgical Site Infection after Emergency Abdominal Surgery in China. Sci Rep. 2021;11(1):1-10.

35. Brennfleck FW, Bachmeier T, Simet W, Zeman F, Junger HHG, Schlitt HJ, et al. Surgical Site Infections and Their Economic Significance in Hepatopancreatobiliary surgery: a Retrospective incidence, cost, and Reimbursement Analysis in a German Centre of the Highest Level of Care. Int Wound J. 2020;18(1):17-23.

36. Alghamdi S, Alawi M, Bokhari R, Bajunaid K, Mukhtar A, Baeesa SS. Risk Factors for Surgical Site Infection following Spinal Surgery in Saudi Arabia. Medicine. 2021;100(17):e25567.

37. Mekhla FR. Determinants of Superficial Surgical Site Infections in Abdominal Surgeries at a Rural Teaching Hospital in Central India: a Prospective Study. J Family Med Prim Care. 2019;8(7):2258.

38. Azeze GG, Bizuneh AD. Surgical Site Infection and Its Associated Factors following Cesarean Section in Ethiopia: a cross-sectional study. BMC Res Notes. 2019;12(1):1-6.

39. Patel S, Thompson D, Innocent S, Narbad V, Selway R, Barkas K. Risk Factors for Surgical Site Infections in Neurosurgery. Ann R Coll Surg Engl. 2019;101(3):220-5.

40. Carvalho RL, Campos CC, Franco LM, Rocha AD, Ercole FF. Incidence and Risk Factors for Surgical Site Infection in General Surgeries. Rev Lat Am Enfermagem [Internet]. 2017;25(0). Available from: https://www.ncbi.nlm.nih.gov/pmc/articles/PMC5738868/

41. Zhang X, Wang Z, Chen J, Wang P, Luo S, Xu X, et al. Incidence and risk factors of surgical site infection following colorectal surgery in China: a national cross-sectional study. BMC Infect Dis. 2020;20(1):111.

42. Mirzashahi B, Tonkaboni A, Chehrassan M, Doosti R, Kharazifard MJ The Role of Poor Oral Health in Surgical Site Infection following Elective Spinal Surgery. Musculoskelet Surg. 2018;103(2):167-71.

43. Khan FU, Fang Y, Khan Z, Khan FU, Malik ZI, Ahmed N, et al. Occurrence, Associated Risk Factors, and Treatment of Surgical Site Infections in Pakistan. Eur J Inflamm. 2020;18:205873922096054. 